\title{
Microtremor and Slope Data of Watukumpul, Pemalang Regency for Landslide Potential Analysis using Simple Additive Weight Method
}

\author{
Urip Nurwijayanto Prabowo ${ }^{1}$, Ayu Fitri Amalia ${ }^{2}$, Heri Nurdiyanto ${ }^{3}$, Robbi Rahim ${ }^{4}$ \\ \{urip.nurwijayanto@ustjogja.ac.id ${ }^{1}$, ayufitriamalia@ustjogja.ac.id ${ }^{2}$ \} \\ Universitas Sarjanawiyata Tamansiswa Yogyakarta, Indonesia ${ }^{1,2}$ \\ STMIK Dharma Wacana, Metro Indonesia ${ }^{3}$ \\ STIM Sukma Medan, Sumatra Utara Indonesia ${ }^{4}$
}

\begin{abstract}
Watukumpul is an area located in central Java which has two active landslide trigger, for example, high slope and earthquake. The aim of this study was to determine the landslide potential area in Watukumpul induced by earthquake and soil slope. We used 33 microtremor measurement data analyzed using Horizontal to Vertical Spectral Ratio (HVSR) and Historical earthquake data between 1988-2018 to calculate ground shear strain (GSS) value that describes the soil dynamics condition when the earthquake occurs. The area has soil slope range between $0^{0}-58^{0}$. The result of ground shear strain calculation ranges between $0.0004-0.0092$. We combined the high slope and GSS value using Simple Additive Weight (SAW) method to make the landslide potential area map. The result of the SAW method showed that the area has medium and high landslide potential.
\end{abstract}

Keywords: Landslide, HVSR, Microtremor, Watukumpul.

\section{Introduction}

Watukumpul is a subdistrict of Pemalang regency located in central Java which is a downhill area with the high slope on the hills. This area has complex geological structures i.e faults, folds and was crossed by some rivers which make river hill along the path [1]. This condition causes landslide occurred in Watukumpul. There were 2 landslides even happened in Gapura village and Tundagan village that damaged houses and public facilities in 2017. Besides that, Central Java has tectonic processes which were deemed to ground motion [2] as well as in Watukumpul. This area has peak ground acceleration value about 0.11-0.15 g [3]. Therefore, Watukumpul has two active landslide triggers, for example, a high slope of elevation and earthquake.

Some landslide parameter could be combined to map the landslide potential area i.e. particle motion and local site effect which conducted from microtremor measurement [4][5]PGA and local site effect that were reflected as ground shear strain value [6]; local site effect, slope of elevation and local site effect [7]; ground shear strain value, rainfall intensity, PGA, Vs30, slope and distance from the fault [8].

In the study, we combined two active landslide trigger in Watukumpul to make landslide potential map as a mitigation effort in terms of both government policy decisions and EWS (Early Warning System) scheme technicalities. Earthquake-prone to ground motion factor was 
investigated using ground shear strain values that describe soil dynamics condition when the earthquake occurs [9]. The ground shear strain was calculated based on PGA values and vulnerability index value $(\mathrm{Kg})$ [10]. We determined $\mathrm{Kg}$ value from microtremor measurement which was analyzed by Horizontal to Vertical Spectral Ratio (HVSR) [11].

Simple Additive Weighting (SAW) [12] used as a weighted statistic method to combined two active landslide trigger in Watukumpul as a landslide potential map.

\section{Geological Setting}

The research area located at the south part of Pemalang regency, central Java. Geological setting of the area consist of alluvium formation (Qa); Halang formation (Tmph); Rambatan formation (Tmr) and diorite intrusion (Tmi(d)) [1] (Fig 1). The area has some faults with southeast-northwest or northeast-southwest orientation.

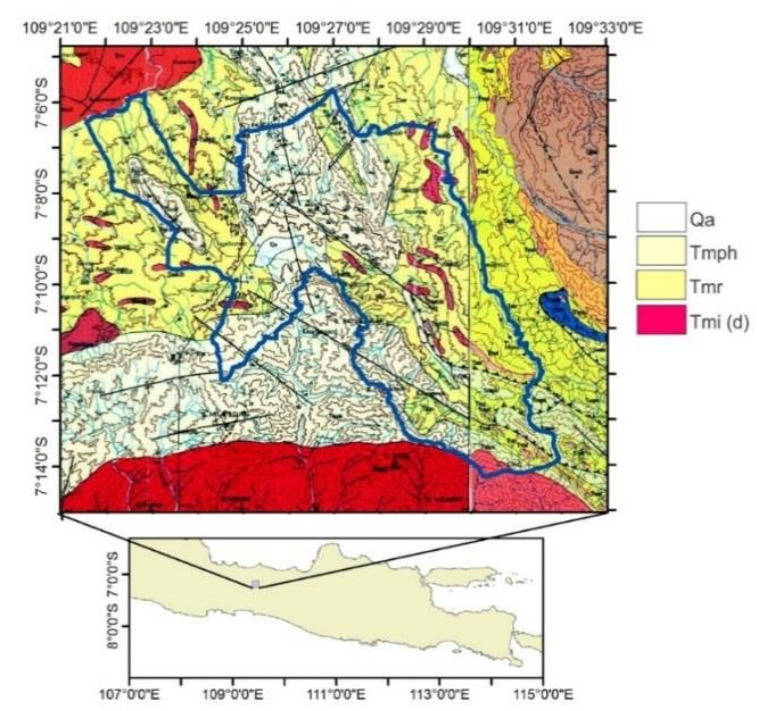

Fig. 1. Geological map of the study area

\section{Material and Methods}

\subsection{Data Acquisition}

The slope data in this study used data from the United States Geological Survey (USGS). The historical earthquake data for the last 30 years (1988-2018) around the area $\left(\mathrm{E} 106^{0}\right.$ $\mathrm{E} 115^{0}$ and $\mathrm{S}\left(-3^{0}\right)-\mathrm{S}\left(-11^{0}\right)$ ) were taken from the International Seismological Center (ISC) which has the magnitude more than 3 . The PGA value use earthquake data. It will use together with the results of the microtremor measurement to determine the value of ground shear strain. 
The microtremor data obtained from measurements in the study area were 33 points using 3 component MAE seismometer (Figure 2). The measurement duration of each point was 20 minutes with a sampling rate of 100 and measurements were carried out in a quiet location to avoid noise in the form of residents' activities or passing vehicles.

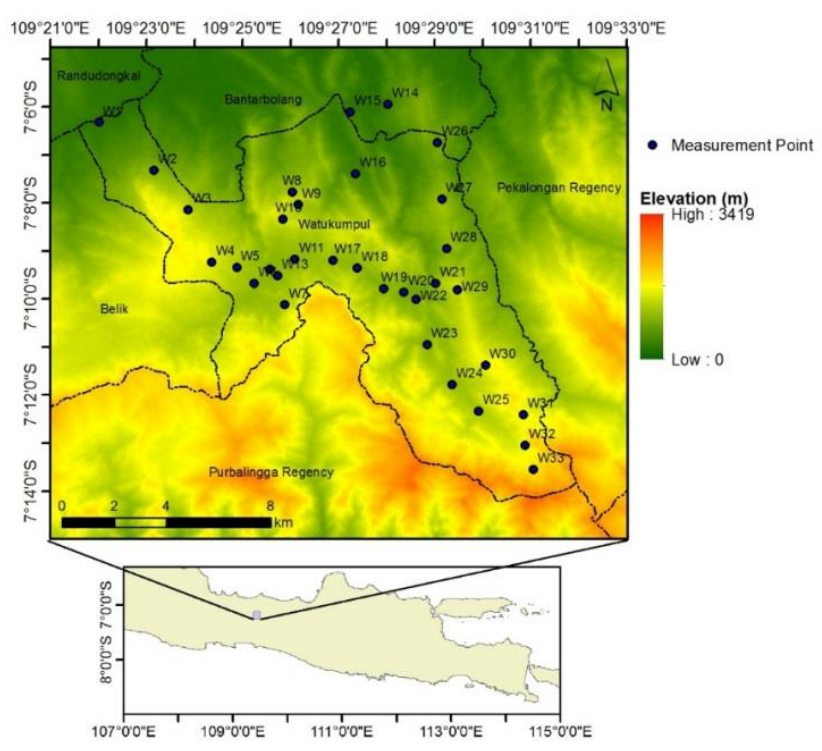

Fig. 2. Microtremor Measurement Location

\subsection{Data Processing and analysis}

The historical earthquake data was proceed to obtain PGA values using Fukushima-Tanaka equation [13] as follows

$$
\log \alpha=0,41 M_{s}-\log \left[R+0,333 \times 10^{0,41 M_{s}}\right]-0,34 R+1,28
$$

where $\alpha$ is the ground vibration acceleration, is the surface wave magnitude and is hypocenter distance. In this study, the value is calculated based on the distance between the hypocenter and the microtremor measurement point.

The 33 point microtremor data were processed using Geopsy software based on the HVSR method which proposed by Nakamura. Data processing criteria follow the criteria of the Sesame project [14]. Data processing results based on HVSR method produce predominant frequency $\left(f_{0}\right)$ and amplification $(A)$ which together with PGA $(\alpha)$ values can be used to calculate the ground shear strain $(\gamma)$ value using the following equation

$$
\gamma=e \frac{A^{2}}{f_{0}} \frac{\alpha}{\pi^{2} v_{b}}
$$


With the assumption that the efficiency of soil dynamic force $(e)$ was $60 \%$ and shear wave velocity value in bedrock layer is $600 \mathrm{~m} / \mathrm{s}$ [15].

\subsection{Data analysis and interpretation}

The soil slope parameter and ground shear strain are combined using the Simple Additive Weight (SAW) method to determine the potential level of landslides. Simple Additive Weight (SAW) method is a multicriteria analysis method to combine several parameters into one decision result by multiplying the index class value of each data parameter with a rating value then adding up the results for all parameters.

The weighting criteria for the two parameters are as Table 1.

Table 1. Weighting criteria for ground shear strain and soil slope (modified from Hadi, et all [8]

\begin{tabular}{ccccc}
\hline Indicator & Criterion Weight & Level of Susceptibility & Index Class & Rating \\
\hline \multirow{2}{*}{ Ground } & & High & GSS $\geq 0.01$ & 3 \\
Shear Strain & 5 & Medium & $0.0001 \leq$ GSS $<0.01$ & 2 \\
& & Low & GSS $<0.0001$ & 1 \\
Slope $\left(^{0}\right)$ & \multirow{2}{*}{3} & High & Slope $>40^{\circ}$ & 3 \\
& & Medium & $25^{0}<$ Slope $<40^{\circ}$ & 2 \\
& & Low & Slope $<25^{0}$ & 1 \\
\hline
\end{tabular}

The results of the SAW method based on Table 1 are normalized values to determine the potential level of landslides with low, medium, and high classifications.

\section{Results and Discussion}

\subsection{Soil Slope}

Based on topography data from USGS we conducted soil slop map of study area that show in Fig 3. The soil slope value range between $0^{0}-58^{0}$ which show that The topography of the area is highly steep. The elevation range between 90-11256 m. An area has high landslide potential if the soil slope more than $40^{\circ}$ [8]. 


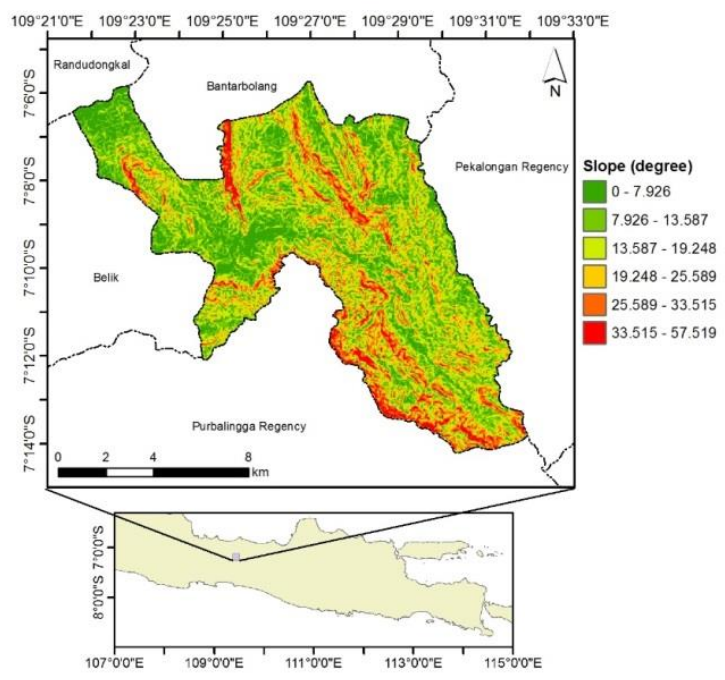

Fig. 3. Soil slope map of the reasearch area

\subsection{Peak Ground Acceleration}

The distribution of PGA values from the calculations in Figure 4 shows that the PGA values range from 18.37 - 21.97 gal with the highest being in the South East and North West areas of the study area. This high value is caused by a source of local fault activity near the study area.

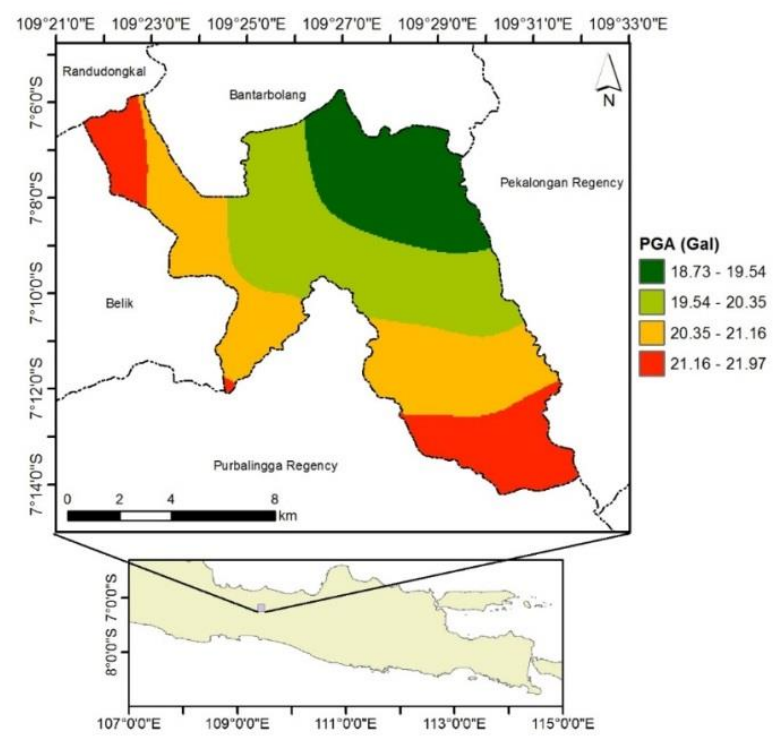

Fig. 4. Peak Ground Acceleration (PGA) distribution map. 


\subsection{HVSR Results}

The results of microtremor measurement data processing using the HVSR method are predominant frequency $\left(f_{0}\right)$ and amplification $(A)$ values from 33 measurement points (Figure 5). Based on Figure 5, the amplification values ranged between 9 - 41.45 . Amplification states the impedance contrast between the surface sediment layer and the bedrock layer below so the amplification values of the area showed that variations in bedrock layers. The amplification values obtained based on the peak HVSR curve are not related to the frequency value dominant but comparable to earthquake wave propagation quality factors (Qs) earthquake and associated with earthquake wave magnification [16]. The research area with the highest amplification value is easily go through to ground motion if an earthquake comes through.

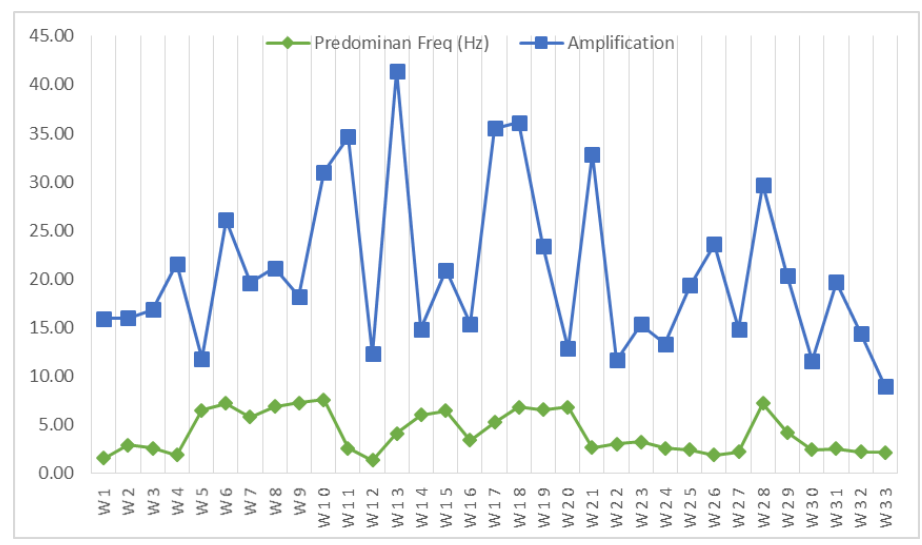

Fig. 5. Predominant frequency $\left(f_{0}\right)$ and amplification $(A)$ values from microtremor measurements.

The dominant frequency of the study area ranged from $1.36-7.62 \mathrm{~Hz}$ (Figure 5) with the distribution of values in the study area can be seen in Figure 6. The frequency obtained from the peak of the HVSR curve showed the thickness of the surface sediment layer of the study area [17], [18]. Based on Figure 6, the research area with high-frequency values (6.56-7.62 $\mathrm{Hz}$ ) was in the village of Majalangu, Watukumpul village and Jojogan village, so that this area is an area with thin/small sediment thickness. an earthquake comes through. 


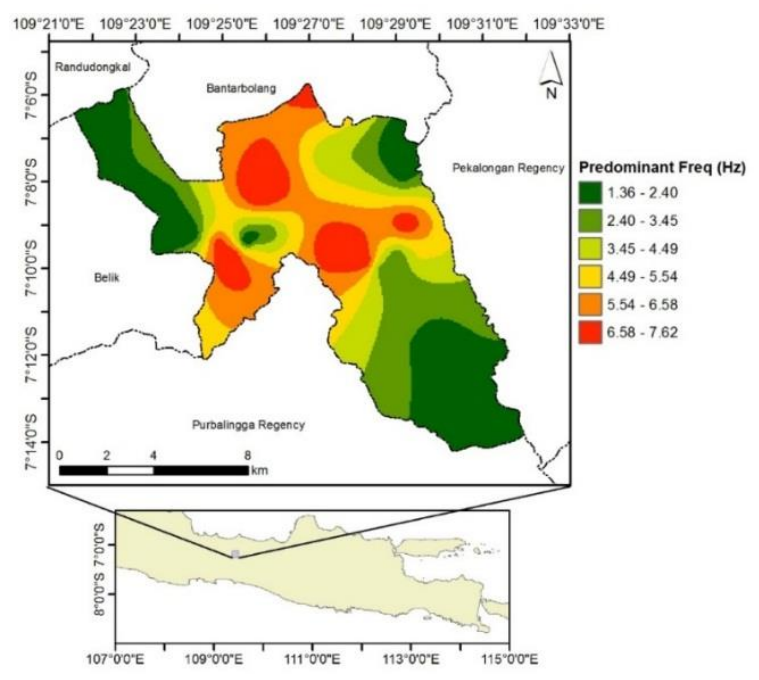

Fig. 6. Predominant frequency distribution map.

\subsection{Ground Shear Strain}

The calculation results of the ground shear stran produced a value that ranges from 0.0004 -0.0092 with the distribution of values shown in Figure 7. The sediment layer will be inelastic and surface deformation in the form of cracks if it has a ground shear strain value of more than 0.001. It will experience a large deformation in the form of liquefaction or landslides if they have ground shear strain value of more than 0.01[10]. So it can be seen in Figure 7 that almost all research areas have the potential for surface deformation if they go through earthquake vibrations.

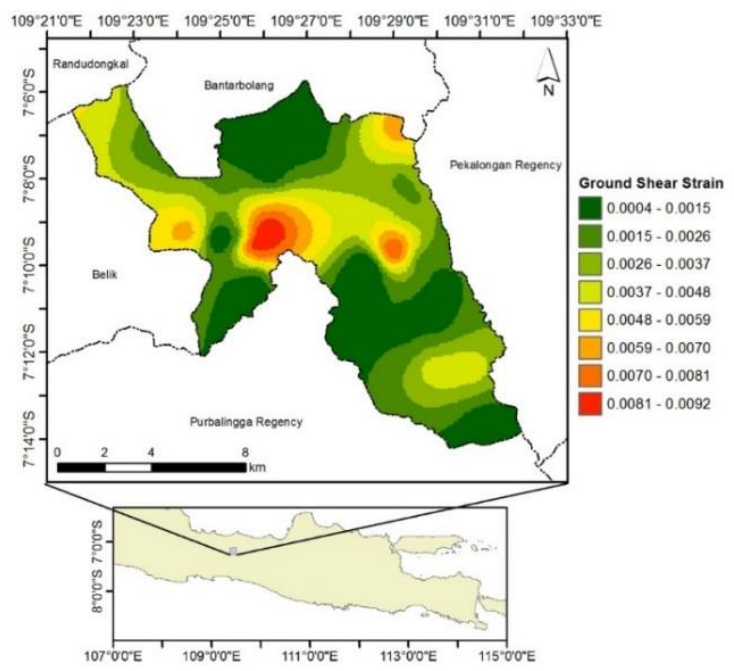

Fig. 7. Ground Shear Strain distribution map 


\subsection{The Landslide Potential Map}

Figure 8 shows the landslide potential map results used the SAW method. The lowfrequency value was in the little part of Tundagan and Cikadu village. This area has a small potential value because it has a ground shear strain value of less than 0.001 . So, it does not go through surface deformation when an earthquake occurs. Values of medium and high lending potential are almost evenly distributed in the study area. The value being contributed by the dominant ground shear strain parameter of the study area was more than 0.001 . The value of high landslide potential is caused by slope factors of more than 400 in the study area with a ground shear strain value of more than 0.001 so that the slope is a very determining factor in the mechanism of landslides in this study. Research on the mechanism of soil movement due to earthquakes in the Yogyakarta area on May 27, 2006 earthquake based on geological studies led to the conclusion that earthquake vibrations can trigger the mass of sediment slope surface go through movement and landslides [19]. The main factor controlling the sediment mass movement is the weathering conditions on slopes steeper than 40 and the orientation of rock layers.

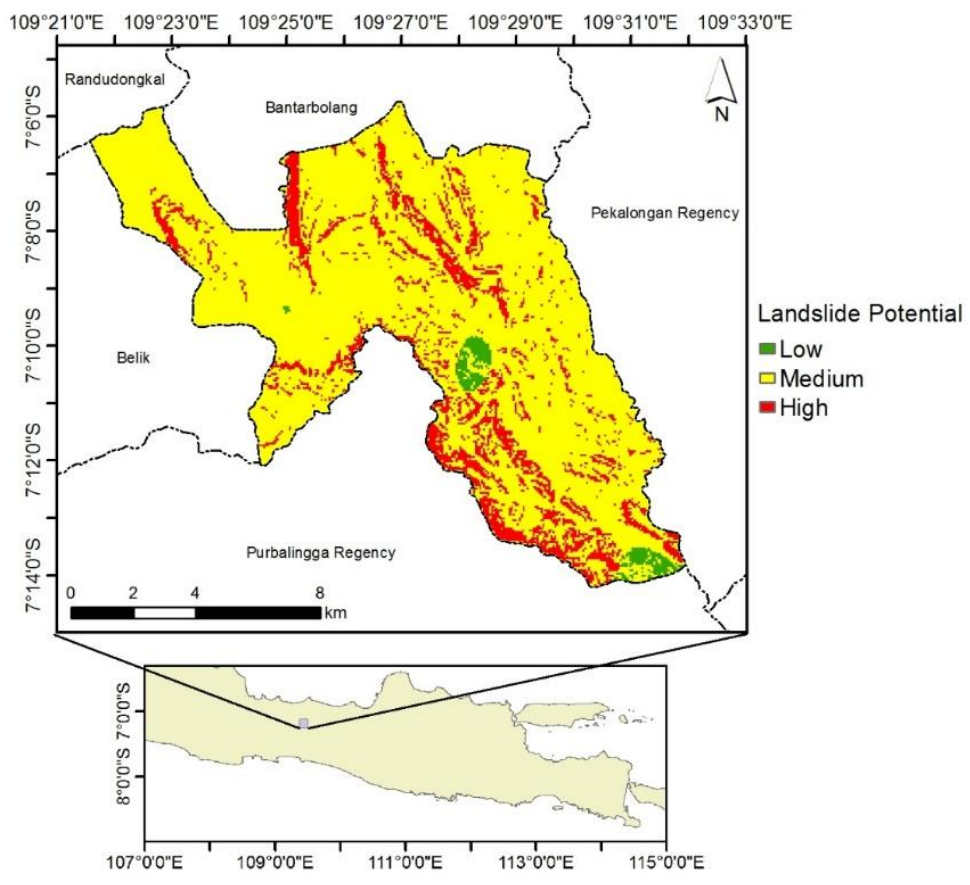

Fig. 8. Landslide Potential Map of Watukumpul

\section{Conclusions}

The result of this study show Watukumpul area dominated by medium and high landslide potential area. The high potential landslide area controlled by soil slope more than $40^{\circ}$. Based on the results of this study, it was suggested that landslide potential map can be used as a 
reference in the mitigation of landslides both in regional spatial planning by local governments and installations of tools for early warning landslide systems by BNPB.

Acknowledgments. We would thanks to DPRM DIKTI who has funded this research through PDP (Penelitian Dosen Pemula) scheme 2018

\section{References}

[1] M. Djuhri, H. Samodra, T. Amin, and S Gafoer, Geological Map of Purwokerto dan Tegal, Jawa. Bandung: Pusat Penelitian dan Pengembangan Geologi, Badan Geologi, 1996.

[2] G. Yuliyanto, U. Harmoko, and S. Widada, "Identification of Potential Ground Motion Using the HVSR Ground Shear Strain Approach in Wirogomo Area, Banyubiru Subdistrict , Semarang Regency,” vol. 11, no. 6, pp. 1497-1507, 2016.

[3] A. L. Ashadi, U. Harmoko, G. Yuliyanto, and S. I. Kaka, "Probabilistic seismichazard analysis for central java province, indonesia," Bull. Seismol. Soc. Am., vol. 105, no. 3, pp. 1711-1720, 2015.

[4] U. N. Prabowo, A. F. Amalia, and F. E. Wiranata, "Identifikasi Potensi Pergerakan Tanah Pada Lereng Yang Dipicu Gempabumi Berdasarkan Pengukuran Mikrotremor," Wahana Fis., vol. 2, no. 2, pp. 1-11, 2017.

[5] S. L. Ramadhany, B., S. Sungkono, A. Rohman, D.D. Warnana, "Comprehensive Analysis of Microtremor data to identify potential landslide S903 Comprehensive Analysis of Microtremor data to identify potential landslide ( Study Case : KM23 Ponorogo- Trenggalek Road )," EAGE-HAGI, 2018.

[6] U. N. Prabowo, A. F. Amalia, and F. E. Wiranata, "Local site effect of soil slope based on microtremor measurement in Samigaluh, Kulon Progo Yogyakarta," J. Phys. Conf. Ser., vol. 997, no. 1, 2018.

[7] A. I. Hadi, Sismanto, and K. S. Brotopuspito, "Landslide Potential Analysis Using Micro-tremor and Slope Data on Bengkulu-Kepahiang Main Road at Km 31-60," IOSR Juornal Appl. Geol. Geophys., vol. 4, no. 5, pp. 9-14, 2016.

[8] A. Hadi, K. Brotopuspito, S. Pramumijoyo, and H. Hardiyatmo, "Regional Landslide Potential Mapping in Earthquake-Prone Areas of Kepahiang Regency, Bengkulu Province, Indonesia," Geosciences, vol. 8, no. 6, p. 219, 2018.

[9] "Isihara, K., 1982, Evaluatian of Soil Properties for Use in Earthquake Response Analysis. Proc. Int. Symp. On Numerical Model in Geomech, 237-259.," p. 1982, 1982.

[10] Y. Nakamura, T. Sato, and M. Nishinaga, "LOCAL SITE EFFECT OF KOBE BASED ON MICROTREMOR MEASUREMENT," in Proc XII World Conf. Earthquake, 2000, pp. 1-21.

[11] Y. Nakamura, "A Method for Dynamic Characteristics Estimation of Subsurface using Microtremor on the Ground Surface," QR RTI, vol. 30, no. 1, pp. 25-33, 1989. 
[12] J. J. H. Setiawan, "MIKROZONASI SEISMISITAS DAERAH YOGYAKARTA DAN SEKITARNYA," Institut Teknologi Bandung, 2009.

[13] Y. Fukhusima and T. Tanaka, "A New Attenuation Relation for Peak Horizontal Acceleration of Strong Earthquake Ground Motion in Japan, Bull of the seismological society of America," in Soc. Am, 1990, pp. 757-783.

[14] P. Bard, A. Duval, A. Koehler, and S. Rao, "Guidelines For The Implementation Of The H / V Spectral Ratio Technique On Ambient Vibrations Measurements , Processing And Interpretation Sesame European research project," no. December, pp. $1-62,2004$.

[15] Y. Nakamura President, "Seismic vulnerability indices for ground and structures using microtremor," vol. 1, pp. 1-7, 1997.

[16] U. N. Prabowo, Marjiyono, and Sismanto, "Amplifikasi dan Atenuasi Gelombang Seismik di Lapisan Sedimen Permukaan," Sciencetech, vol. 2, no. No 1April2016, p. $5,2016$.

[17] M. I. V Seht and J. Wohlenberg, "Microtremor Measurements Used to Map Thickness of Soft Sediments," Bull. Seismol. Soc. Am., vol. 89, no. 1, pp. 250-259, 1999.

[18] R. S. Marjiyono, Ratdomopurbo, Suharna, Moch. Heri Hermiyanto Zajuli, "Geologi bawah permukaan dataran klaten berdasarkan interpretasi data mikrotremor," J. Geol. Sumberd. Miner., vol. 15, no. 1, pp. 3-10, 2014.

[19] R. A. and S. H. D Karnawati, S Pramumijoyo, Earthquake induced landslide at Sengir, Prambanan district Yogyakarta The Yogyakarta Earthquake of May 27, 2006, vol. 1, no. 9. Yogyakarta: Star Publishing Company, 2008. 